\title{
Promoting Excellence: Good to Great, NYC's District 2, and the Case of a High Performing School District ${ }^{1}$
}

\author{
Alex J. Bowers ${ }^{2}$ \\ Teachers College, Columbia University ${ }^{3}$ \\ Bowers@tc.edu
}

\begin{abstract}
This paper compares two celebrated studies - New York City Community School District 2 (Elmore \& Burney, 1999), and Good to Great (Collins, 2001) which examined sustained success in American corporations - to the case of a single high performing school district. The question of interest concerns how school districts achieve and maintain high performance. The study focuses on five central issues from a combined theory from District 2 and Good to Great: 1) An organization-wide disciplined system that provides boundaries for participants but allows for creativity and innovation within those boundaries. 2) A central defined organizational focus that drives day-to-day decisions and is separate from an organization's vision and mission. 3) Getting the right people into the organization through innovative hiring and training practices. 4) Funneling budgetary resources to district priorities through multi-pocket budgeting. 5) And a long-term commitment to success through continuous improvement while maintaining a focus on the current challenges facing the organization.
\end{abstract}

Keywords: districts, data driven decision making, administration, leadership, whole school reform, Success for All, continuous improvement, vision, mission, data, human resources, hiring, substitutes, finances, budget

\section{INTRODUCTION}

The problems facing American school districts are many and varied (Hightower et al., 2002; Marsh, 2002; McLaughlin \& Talbert, 2002; Skrla \& Scheurich, 2004), but questions persist as to how and whether at least some districts achieve long-term high performance. A prior line of school effectiveness research detailed many cases of higher performing schools, but this work was limited in its focus on schools, a lack of longitudinal data, a constricted range of outcomes, and attention to specific governmental policy issues (Coe \& Taylor-Fitz-Gibbon, 1998; Goldstein \& Woodhouse, 2000; Teddlie et al., 2000; Thrupp, 2001). More recently some studies have examined and compared school districts that have achieved excellence in multiple dimensions of their organizations (Hightower, 2002; Murphy \&

\footnotetext{
${ }^{1}$ This document is a pre-print of this manuscript, published in 2008 in the journal Leadership and Policy in Schools. Recommended citation:

Bowers, A.J. (2008) Promoting Excellence: Good to Great, NYC's District 2, and the Case of a High Performing School District, Leadership and Policy in Schools, 7(2), 154-177. doi:10.1080/15700760701681108

${ }^{2} 525$ W. $120^{\text {th }}$ Street, New York, New York 10027. ORCID: 0000-0002-5140-6428, ResearcherID: C-1557-2013

${ }^{3}$ Formerly at The University of Texas at San Antonio at the time of publication.

Note: This document was last updated July 23, 2013
}

Hallinger, 2001; Snyder, 2002; Supovitz, 2006). One of the primary exemplars of an instructionally effective and organizationally coherent school district is New York City Community School District \#2 (Elmore \& Burney, 1997, 1999; Fink \& Resnick, 2001; Stein \& D'Amico, 2002a, 2002b). Interestingly, many parallels can be drawn between District 2 and Good to Great (Collins, 2001) a recent study of American corporate effectiveness, coherence, and leadership. Although highly similar in their conclusions these two studies provide an attractive conceptual ambit for studying current school districts. The purpose of this case study is to examine how the District 2 and Good to Great exemplars might inform the study of a high performing mid-western American school district.

\section{Effective Organizations: Background and Theory}

Recent theories have emerged detailing how instructional resources are distributed within an educational organization and how that distribution facilitates coherent and focused instruction, known as "instructional regimes" (Cohen et al., 2003; Raudenbush, 2005). These regimes bring together all aspects of the organization to focus organizational constituents and empower them to succeed. Similarly, in the current study, it is argued from the perspective of a combined theory of District 2 (Elmore \& Burney, 1997, 1999) and Good to Great (Collins, 2001) that these integrated systems (AKA instructional regimes) bring together all levels of the organization to focus on the most pressing issues, through funneling all resources toward systemwide goals.

Research on this type of system-wide organizational focus in educational organizations is sparse, but one study outside of education helps provide foundation and insight. Jim Collins and his team in Good to Great used longitudinal data to examine eleven exemplary American corporations that had experienced high and sustained performance over twenty to thirty years, and compared them to seventeen corporations that either had high but unsustained growth during the same period, or were low-growth comparison companies to the top eleven (Collins, 2001). Through these comparisons, Collins found many details that were consistent across all eleven corporations, and has recently extended these findings into the realm of the social sector (Collins, 2005). Central to the findings was the leader, a person who exuded ambition for the organization, not for her or himself. These leaders were modest and understated, but felt a compulsion to work diligently to produce sustained results. The leader removed low performing or uncooperative executives and replaced them with people who could confront the facts facing the organization, work cooperatively and create innovative solutions together in an effort to continually define and redefine the core competency and focus of the corporation. With a laser-like focus on understanding the core competency of the business, the leadership teams then set about piloting small systems and solutions. With continued long-term cycles of trial and success, 
they built a disciplined culture in which employees adhered to a consistent organization-wide system, but had freedom and responsibility within the boundaries of that system. In addition, these companies used their budgets creatively to focus resources on the core competency of the business, while eliminating funding for any component that did not support that focus. Through these actions, the eleven corporations slowly transformed, creating a new focused culture that encouraged dialogue, data driven decision making, and the careful selection of specific systems and technology.

Among the few studies on a system-wide focus in school district organizations, the example of high performance and instructional improvement in New York City Community District \#2 during the 1990s stands out (Elmore \& Burney, 1997, 1999; Fink \& Resnick, 2001; Stein \& D'Amico, 2002a, 2002b). In these studies, five main themes emerged. First, under the leadership of the superintendent, instruction became the main focus of the district. The central office and schools made instruction the top priority for all actors within the district, in this case using the Balanced Literacy program as a vehicle to build shared expertise of teachers, staff, and students. Second, through the implementation of a single coherent district-wide instructional improvement strategy, the district took on a long, multi-staged process that encouraged professional development, dialogue, collaborative planning, and reflection on performance across the district. Third, entrenched and uncooperative staff were replaced to bring together fresh talent and ideas around the implementation of the new instructional system. Fourth, multiple streams of funding were acquired through grants and government programs and funneled to specific purposes to support the instructional strategy, called "multi-pocket budgeting" (Elmore \& Burney, 1999). These changes created a new culture in District 2 focused on the central theme of system-wide instructional improvement. ${ }^{4}$

Together, District 2 and Good to Great reveal similarities in which the organizations studied focused their resources, both monetary and intellectual, on system-wide goals. In this study, these two theoretical frames are brought together into an integrated theory and initially tested. This combined theory details five main issues. First, leaders created an organizationwide disciplined system through providing boundaries for participants but allowing for innovation and creativity within that system. Second, day-to-day district decisions were driven by a defined organizational focus that was separate from a vision or mission. Third, hiring and training of teachers was a central focus. Fourth, through multi-pocket budgeting, budgetary resources were funneled to the district priorities. And fifth, the organization maintained a long-term commitment to success while acknowledging current areas in need of improvement. To initially test the value of these ideas, this study examines one $\mathrm{K}$ 12 school district that presented a record of sustained high performance by first reviewing the record of performance for that district, then considering each of these five main themes in turn,

\footnotetext{
${ }^{4}$ While the District 2 story is compelling, the effort to translate these principles into the setting of the San Diego Public Schools apparently has stalled and its future there is uncertain. Final evaluations are not yet complete, but the San Diego case reminds us once again about the complex interaction between context and reform. For additional details on the San Diego case, see Darling-Hammond, et al., 2005; Hess, 2005.
}

Bowers, A.J. (2008) Promoting Excellence from the perspective of District 2, and Good to Great, with initial supporting evidence provided from the district case.

\section{METHOD}

\section{District Selection}

To choose a district, multiple regression was used to analyze all of the districts in a single mid-Western state, with composite district-level state test scores for reading, writing, and mathematics at the elementary, middle and high school levels as the outcome. Variables with statistical significance were identified and schools were ranked based on the difference between their actual composite state test score and the predicted composite state test score. The district with the largest positive difference was selected for further study ${ }^{5}$. The selected district, Middleville (a pseudonym), was examined as a case study (Yin, 2003) as part of a larger study of high performing districts, in which semi-structured face-to-face interviews were conducted with the district superintendent, assistant superintendent, all principals and assistant principals, a cross-section of teachers in each school, and all district instructional facilitators. Teachers were selected for interviews in two ways. First, the district suggested and scheduled 45 minute interviews with a selection of teachers, each school's principal and assistant principal, and the central office. Second, over 30 individual classrooms throughout the district were observed at the researcher's discretion for 45 minutes without suggestion from the district administration and then teachers were asked to participate in 45 minute follow-up interviews. In this way, over $40 \%$ of the teaching staff within the district at the elementary level, and over $25 \%$ at the middle and high school levels were interviewed, about half district selected and half researcher selected. This resulted in interviews of 59 individual teachers, 8 principals, 2 assistant principals, 6 instructional facilitators and 11 central office personnel, including three interviews of both the superintendent and assistant superintendent. Interview questions included such questions as: What would you say are the main priorities of the district? How have these been communicated to you? How do you decide what you teach in your classroom? How do you decide how you teach in your classroom? How you do feel about your ability to help all your students learn? How do you assess for student learning? How do you manage pacing of your curriculum? To whom are you accountable to in the district? And how are decisions made here? The interviews were tape-recorded and transcribed verbatim as were field notes taken during the site visits.

Multiple documents were also collected which included the district website, all current promotional pamphlets and brochures that were distributed to parents during the time of the study, district calendars for faculty meetings and events, district newsletters and local newspaper articles on the school district from 1999 through 2006. The Middleville data were analyzed using a theoretical framework that was constructed through

\footnotetext{
${ }^{5}$ It is acknowledged that state test scores that show that a district is performing well above state averages are only single measures of performance, and do not exclusively provide evidence of district excellence. However, in combination with regression analysis, test scores do provide an initial means to compare districts with the intent to select a single high performing district from among all districts in a state for in-depth qualitative analysis to study how a district may be promoting high performance.
} 
examination and comparison of the similarities between the theories presented in Good to Great and District 2, creating a combined theory (discussed below). Transcripts were examined to explore evidence of the combined theory from Good to Great and District 2 and will be detailed in turn below.

\section{District Background and Context}

The district is the urban center for a community of about 20,000 residents that serves about 3,000 students in six elementary schools, a middle, and a high school. The district was selected based on its demographic composition (33\% African American, 58\% European American, 49\% economically disadvantaged), its overall consistent multi-year high state test scores at the elementary level (over $80 \%$ proficient in reading, writing and math 2001-2006), and its narrow achievement gaps between demographic groups across elementary schools, (Standard \& Poor's, 2005). The district superintendent at the time of the study had served in multiple roles throughout the district, including the high school principal and assistant superintendent, and had been superintendent for three years prior to the study.

\section{RESULTS AND ANALYSIS}

\section{The Middleville School District}

While this study is focused on the identification and analysis of high performing and excellent organizations it cannot claim that Middleville is performing in exemplary fashion across its entire organization. Rather, the district was chosen as the site for the analysis of the theoretical framework because it has some of the highest state test scores for its state, yet still faces significant challenges. Middleville is a high performing school district in mathematics, reading and writing at the elementary level. For the state mathematics, reading and writing proficiency assessments from academic years 2000-01 to 2005-06, Middleville consistently out-performed the state's mean proficiency levels at the fourth grade level, but lagged behind the state means on state high school assessments (Figure 1). At the grade 4 elementary school level, Middleville students consistently scored within or above one standard deviation above the state mean assessment scores in both mathematics and reading, and showed marked gains year-to-year in writing (Figure 1, left-side, A, B and C). Thus, at the elementary level, Middleville can be considered a high performing organization that is finding success with its students. In contrast, as is true of many school districts in the United States, the case becomes more complex when state test scores at the high school level are examined ${ }^{6}$. For the high school level, Middleville students consistently score below or at the state mean in mathematics, reading and writing, and for many years far below one standard deviation (Figure 1, right-side, A, B and C). However, the year-to-year trend data suggests improvements over time for the district's high school students, as the district's state assessment scores approached the state means. Taken together, these data indicate that while Middleville was below the state performance assessment average at the high school level, at the elementary level the district far outperformed the state averages in multiple subjects. Middleville appears to be on the path from

\footnotetext{
${ }^{6}$ Of note, as a comparison to Middleville, NYC's District 2 included only K-8 schools and so did not face the distinctive challenges posed by high schools
}

Bowers, A.J. (2008) Promoting Excellence good to great, recognizing both success at the elementary levels and the need to improve at the higher grade levels.
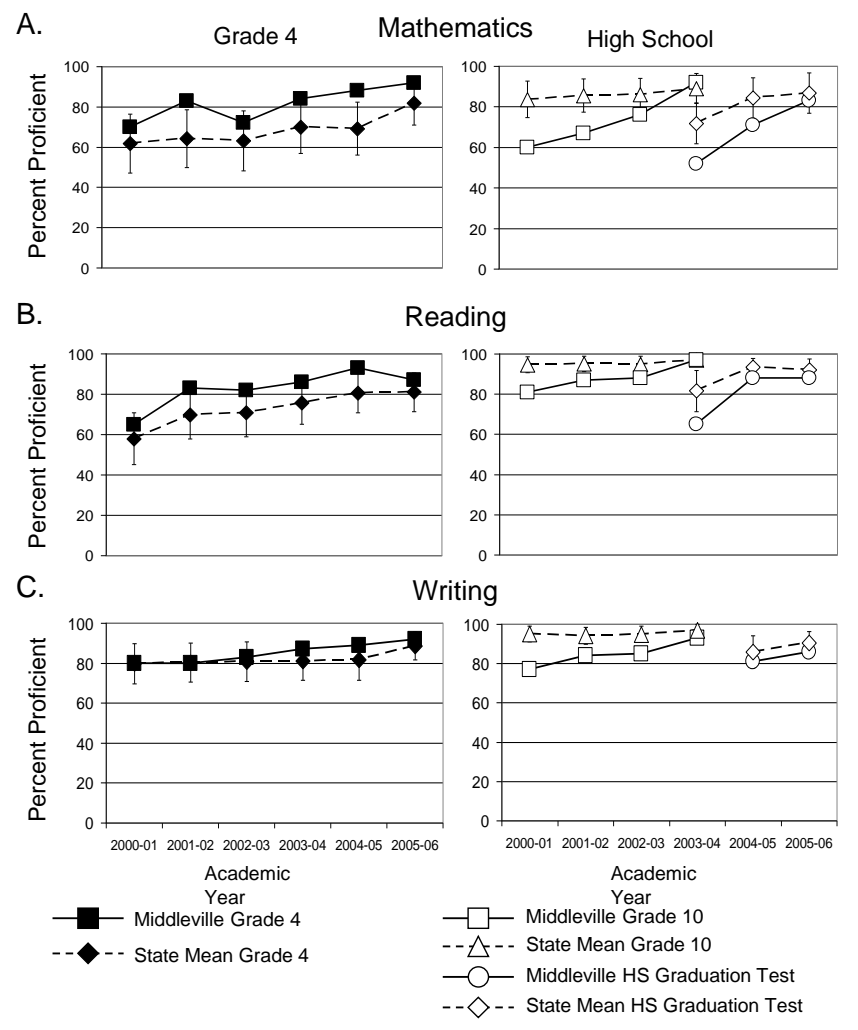

Figure 1: Middleville State Standardized Test Proficiencies. Middleville grade 4 and high school state standardized test proficiencies in comparison to state means are shown for mathematics $(A)$, reading $(B)$, and writing $(C)$. Error bars for state means represent $+/-1$ standard deviation. The state grade 10 tests were replaced by high school graduation tests in year 2003-04 for mathematics and reading, year 2004-05 for writing.

\section{The District 2 and Good to Great Accounts}

Together, District 2 and Good to Great reveal similarities in how organizations focus resources, both monetary and intellectual, on system-wide goals. This study proposes that through examining the core components of these two formative studies a combined framework may be tested on the case of Middleville. Interestingly, each major aspect of the Good to Great study has a corresponding aspect in the District 2 study that relates closely to evidence provided from Middleville (Table 1). Each major component will be considered in turn.

\section{An Organization-Wide Disciplined System}

A major finding of both the District 2 and Good to Great studies is that whether an urban school district or a profit oriented firm, successful organizations focus on creating an overall system that integrates form and function while channeling the efforts of the employees toward a common goal. As Collins (2001) states: "The good-to-great companies built a consistent system with clear constraints, but they also gave people freedom and responsibility within the framework of that system. They...managed the system, not the people" (p.125). In education, this idea of a consistent organizational system has been framed in terms of coherent instructional guidance, in which curriculum frameworks, curricula, instructional activities, and professional development 
within a school system all focus on a common vision of both what and how children should learn (Murphy \& Hallinger, 2001; Smith \& O'Day, 1991). This focus on implementing consistent systems in which clear purposes, development and boundaries are set within which people are free to innovate was also found in District 2. Through the implementation of the Balanced Literacy program, which stressed reading as the core component of learning at the instructional level, the leaders of District 2 were able to provide clear curriculum frameworks, a common set of instructional materials, targeted external and consulting services, and in-depth professional development centered on the Balanced Literacy concept (Stein \& D'Amico, 2002b). Together, the cases of the Good to Great companies combined with District 2 indicate that for school districts, gathering the functions of the organization around a central coherent and consistent system gives teachers and administrators a common set of purposes. These in turn guide professional development, curricular decisions, and daily classroom practice, giving all participants in the system a common language as professionals to share experiences, ask questions and build a common practice.

Table 1: Five Key Concepts of a Combined Theory of Successful Organizations

\begin{tabular}{c|c|c|c} 
Combined Theory & Good to Great & District \#2 & Middleville \\
\hline $\begin{array}{c}\text { Organization-wide } \\
\text { disciplined system }\end{array}$ & Culture of discipline & Balanced Literacy & $\begin{array}{c}\text { Success For All } \\
\text { (SFA) }\end{array}$ \\
\hline $\begin{array}{c}\text { Central defined } \\
\text { organizational focus }\end{array}$ & Hedgehog Concept & $\begin{array}{c}\text { It's about } \\
\text { instruction, and only } \\
\text { about instruction }\end{array}$ & $\begin{array}{c}\text { Every child at or } \\
\text { above grade level } \\
\text { when they leave that } \\
\text { grade level }\end{array}$ \\
\hline $\begin{array}{c}\text { Getting the right } \\
\text { people into the } \\
\text { organization }\end{array}$ & $\begin{array}{c}\text { Right people on the } \\
\text { bus }\end{array}$ & $\begin{array}{c}\text { Removal of staff } \\
\text { who did not match } \\
\text { with the system }\end{array}$ & $\begin{array}{c}\text { Hiring only subs } \\
\text { who work well with } \\
\text { the district }\end{array}$ \\
\hline $\begin{array}{c}\text { Funneling } \\
\text { budgetary resources } \\
\text { to districtpriorities }\end{array}$ & $\begin{array}{c}\text { The budgeting } \\
\text { concept }\end{array}$ & $\begin{array}{c}\text { Multi-pocket } \\
\text { budgeting }\end{array}$ & $\begin{array}{c}\text { Multi-pocket } \\
\text { budgeting }\end{array}$ \\
\hline $\begin{array}{c}\text { Long-termfaith and } \\
\text { contimuous } \\
\text { improvement }\end{array}$ & $\begin{array}{c}\text { Retain faith in } \\
\text { prevailing in the } \\
\text { end, but confront } \\
\text { the hard facts }\end{array}$ & $\begin{array}{c}\text { Talented people } \\
\text { working together on } \\
\text { system-wide } \\
\text { improvement }\end{array}$ & $\begin{array}{c}\text { High expectations } \\
\text { with continuous } \\
\text { improvement }\end{array}$ \\
\hline
\end{tabular}

As an organization on the trajectory from good to great Middleville aligns well with Collins' companies and District 2; the key in this case has been the implementation of a nationally recognized whole school reform model, Success for All (SFA) at the elementary level. SFA focuses on cooperative learning in both reading and mathematics; individualized instruction through allowing students to test into more challenging classes every nine weeks; an entire curriculum framework aligned to state standards that provides the same instructional materials to every teacher and classroom each week; instructional facilitators in every school who model and train teachers in SFA; structured professional development centered on the core technology of SFA; and a focus on parent involvement (Slavin \& Madden, 2001a). The implementation of SFA is a complex and system-wide endeavor, that if done haphazardly - a "low implementation level"-in which teachers do not fully support the system, use the instructional materials, implement only aspects of the total program, or do not follow the curricular plan, may degrade both teaching and learning. If the fidelity of the implementation is high then students in elementary school can make significant achievement gains over their peers in non-SFA schools (Borman et al., 2005; Slavin \& Madden, 2001b). Middleville is a case of high fidelity implementation of the organization-wide disciplined system of SFA.

Middleville implemented SFA reading across all of its six elementary schools in 1999, and one year later the SFA math component. Prior to the implementation of SFA, each school was allowed to pursue its curriculum separately. At the time of this study, Middleville was in its sixth and seventh year of SFA implementation. SFA technology provided Middleville with one agreed upon instructional system that the entire organization was practicing, learning, and improving upon. When asked about the implementation of SFA and about using the same instructional system across all of the elementary schools in a district, the superintendent stated:

The teachers had to convert what they were doing. Some of our veteran teachers initially were saying 'this is too structured'. But in the end, they have come to agree that it's better to teach everyone, one structured approach and then you can be free to take it up a notch or be creative in your teaching methodology.

Adoption of this reform suggests compatibility with principles derived from both the District 2 and Good to Great studies. Implementation of SFA has allowed Middleville to create a consistent system while still allowing for innovation and creativity within its parameters once the system has undergone a district-wide and consistent implementation.

Interestingly, previous studies of whole school reform, and SFA in particular, have shown that teachers tend to make adaptations to the structured curriculum of SFA, in many instances decreasing the fidelity to which the program is implemented (Datnow \& Castellano, 2000; Datnow et al., 2002). In the case of Middleville, it appears that teachers were encouraged to follow the curriculum and pacing guides closely for the first few years of implementation, but were then allowed to begin to make adaptations to the curriculum. When asked about the shift from resistance to the structured SFA curriculum to the acceptance mentioned by the superintendent above, in reference to why teachers changed their minds, an elementary teacher stated: "I think because SFA is so scripted and it tells you exactly what to do, every single day was planned out. If you follow that then you get accustomed to it." The teacher went on to say, "and then it does help the teacher that maybe isn't quite as organized as another teacher because it [SFA] really spells it out."

Similar to past findings about SFA implementation (Datnow \& Castellano, 2000) this study found that teachers initially chaffed against the routines of SFA, but once results were experienced by teachers, they began to buy into the program. An elementary teacher stated, "the people who resisted change, and of course you still have a few, but the others, after they've gotten into the program and made it their own, they said oh, why did I ever do that. They loved it." Thus, SFA appears to have been met with some resistance initially, but as teachers have followed the curriculum frameworks and pacing guides, the perception of the program appears to be on the positive side. As stated by one of the elementary principals:

With adopting the SFA program and the people buying into and realizing after the first year that it was working, it became a part of us whether they 
wanted to admit or realize it for sure or not. It actually became a part of everyone's teaching style and it's flexible enough that they could put their style into it too and they could fit and make it work.

Hence, with initial close adherence to the SFA program, the district began to see results, and as it was acknowledged that as teachers were following the program they were allowed to begin to be creative while remaining within the boundaries of the organization-wide system of SFA, adapting to the local needs of their classrooms. As an example, an elementary teacher stated: "I think that every teacher here has their own unique way of teaching SFA. I mean you can go into a classroom and everybody's on Day 1 [of the pacing guide], but everybody probably is doing their own... [sic] you know, we're all different personalities." When asked further if teachers were allowed to change the SFA pacing and program at all, the same teacher responded:

Oh absolutely. Maybe the first year it didn't, but like today, when I was playing marbles. I would have never done that the first year of SFA. Or even the first couple of years. Because it didn't say 'show the kids how to play marbles'. But, we're reading about this marble game, and they don't know how to play marbles. So I just drew a circle and we played it, and they had a great time.

In this way, SFA provided both the consistent system and clear constraints of an organization-wide disciplined system while allowing creativity within the boundaries of the system.

With respect to this issue, termed in the past as "tight-loose management" (Peters \& Waterman, 1982), several trajectories appeared to interact. First, teacher resistance to the structured approach of the SFA program appears to have transitioned from resistance to acceptance. Second, as previously detailed in whole school reform (Datnow et al., 2002), teachers who may have needed additional structure to help plan and implement their instructional practice, such as new teachers, were aided by the structured approach of the SFA program. And third, it appears that teachers were able to move from initial routine instructional practices, following the structure of SFA closely, to more nonroutine practices after building familiarity with the program. The result of these interacting elements was the space to adapt and be creative within the implementation of an overall specified system.

In this case overall, the participants indicated that four major factors that link directly with the SFA program appeared to be significant. First, this district used SFA to provide a consistent source for curriculum, professional development, instructional materials, and instructional pacing, putting all administrators, teachers, substitutes, and district staff, somewhat literally, on the same page. Second, in-school daily professional development from each elementary school's full-time SFA facilitator created an environment where teachers were encouraged to ask questions, share and model effective instructional experiences, and collaborate on individual student needs as time was freed up from needing to decide daily on the next day's instructional plan and materials. Consistently across interviews, teachers commented on how the daily interaction with a school-wide SFA instructional specialist, the in-school SFA facilitator, encouraged them to speak openly about their practice and learn from what was working in other's classrooms, while at the same time providing the needed instructional materials for tomorrow's class, freeing the teachers to engage in these conversations.. Third, the SFA program provides fine-grained periodic assessments of every child in reading and mathematics, allowing teachers not only to concentrate on each student's individual academic needs, but also to know what those needs were in relation to the SFA program, and how the system should respond. Fourth, through the SFA program, parents were involved daily in their child's education, through signing their child's homework to affirm that it had been completed, and in attending periodic family support meetings at their child's school, during which the principal, multiple teachers, and the parent discuss the child's progress.

As one example of how an organization-wide disciplined system looks in action consider this response by the assistant superintendent of Middleville when asked about how the district knows if the children are succeeding in this system:

We're giving the facilitators data and information. We're asking them questions. Where are your kids [scoring]? How did your reading test go? We say to the principals we're having a meeting and we're going to evaluate where your kids are. Do you know where your kids are? Can you tell us where your kids are? So the principals know that it's extremely important that they have this data that helps them look at where we're headed and what we're trying to accomplish and how successful we're being or not. The facilitators know it's important that every kid gets tested at whatever point. Now you take the components of our SFA. One aspect is the family support meetings. You go to a family support meeting and you whip out data. This is where your kid started, where he has completed these many tests. Here's this, here's that. You now can say if he is not successful and here are the reasons why. If he is successful, here are the reasons why. And if he's not successful when he's done $\mathrm{X}, \mathrm{Y}$ and $\mathrm{Z}$, then we're testing that kid and looking at him for other kinds of problems. So there's a whole combination of things going on a regular basis.

He immediately refers to the use of fine-grained assessment and how the system helps organize and understand information to help children, parents, teachers and administrators be successful. For its elementary schools, then, as in Good to Great and District 2, Middleville has a coherent, disciplined and shared approach. This adheres to the principles of creating a single, encompassing system that sets boundaries, creates production routines, and maintains and assesses its performance.

\section{Central Defined Organizational Focus: The Hedgehog Concept}

Authors of both the District 2 and Good to Great studies propose a dedicated focus on the core function of the organization as a primary driver of success. In District 2, Elmore (1999, p.266) claims that, "it is about instruction and only about instruction" unlike many school districts that give nominal attention to such an emphasis. In practice this involved district administrators and principals adhering to a requirement to be present in classrooms daily, see themselves not as administrators but as instructional leaders, and invest heavily in focused structured professional development centered on the core philosophies of the district. In Good to Great, Collins terms this the "hedgehog concept", a reference to Isaiah Berlin's (Berlin, 1953) famous observation 
that, "the fox knows many things but the hedgehog knows one big thing". For both the Good to Great companies and District 2, knowing one big thing was a core component of their success. This continual process of focusing and refocusing on understanding the core competency of the organization ensured that these firms were not distracted by fads or short-term developments in the marketplace. Together, District 2 and Good to Great point to keeping the core focus of the organization on understanding what it is the organization is there to do, and then aligning, and realigning the organization to that "hedgehog concept".

For Middleville, the hedgehog concept of the organization is clear: every child at or above grade level when he or she leaves that grade level. When asked about the priorities of the district, the superintendent responded:

Every grade level we want to make the kids ready for the next one academically so one of the first things that we want to do is to try to have kids be at grade level or higher by the time they leave their [current] grade level, especially in reading and math. Before SFA, you could go to an elementary school and you could say to them hey, how many kids do you have reading below level? They couldn't tell you.

This idea that the central priority of the district is to have children on-grade level with a special focus on reading and mathematics through SFA was also echoed by the teachers and principals. When asked about the district priorities, one elementary teacher said, "basically the district feels that the major focus is on reading and math... We've adopted curriculum [SFA] for reading and math." The middle school principal stated: "They always want me working toward getting as many kids to achieve in all subjects, but especially I would say the emphasis is with reading and math." He later added, "Our job here is to prepare you for the next three years, prepare you for going to the high school". While the overall goals of increasing reading and mathematics achievement appear to have been picked up from SFA, the district appears to have embraced those goals and focused district action on helping students prepare for the following grades, especially in reading and mathematics.

Of note, in Middleville as in Good to Great and District 2, the hedgehog concept is not the vision or mission of the organization traditionally conceived as the values and long term aspirations held by leaders (Hallinger \& Heck, 2002). As a point, when asked specifically about his vision and mission for Middleville, the Superintendent responded that,

As far as vision goes, we want to be the best school in reading, math, and science. We want our kids to be able to get along with one another and to understand about the service to the community, that it's important that they're part of a bigger thing and we want kids to be prepared for a career... whether it be after college or after high school.

This is a classic vision statement. However, it is not the hedgehog concept. As Collins (2001) states: "A Hedgehog Concept is not a goal to be the best ... It is an understanding of what you can be the best at" (p.98). For the successful organization, knowing its hedgehog concept is crucial for its success. Visions and missions are inherently abstractions and values that can not be measured
(Hallinger \& Heck, 2002); however the hedgehog concept holds up a standard against which the organization must gauge its success. For Middleville, the hedgehog concept of "every child at or above grade level when he or she leaves that grade level" is highly defined, is measurable, is source for professional development and creates accountability for each student, teacher, and school. The hedgehog concept focuses the organization on just what it is the best at, and helps that organization maintain that focus.

\section{Getting the Right People into the Organization}

An essential component of both Good to Great and District 2 was hiring talented people who fit within the systems and dismissing personnel who did not. In District 2, the leaders spent a large amount of time devoted to evaluating current staff, providing professional development targeted to the instructional core, and removing staff who either did not match well with the system or did not perform (Elmore \& Burney, 1999). In Good to Great, Collins (2001) uses the metaphor "getting the right people on the bus" (p.41). Interestingly, a major point of Collins' study is that the leaders of the Good to Great companies first got "the right people on the bus ... and the wrong people off the bus" (p. 41) and then leveraged the collective talent of those people as a team to figure out where the bus should go, e.g. the company's hedgehog strategy. However, for schools confronted by union issues, long-term contracts, and tenure, the issue of getting the wrong people off the bus is more complex. Collins has recently addressed this issue in the context of the social sectors, "where getting the wrong people off the bus can be more difficult than in a business, [such that] early assessment mechanisms turn out to be more important than hiring mechanisms" (Collins, 2005). Middleville provides an interesting solution to this human resource issue. The assistant superintendent said,

We hire 100-day subs . . . and they're part of teaching SFA . . Besides, if somebody's absent, they're there. But most importantly, you know, so some school systems will be like, you're spending money on that? Why would you spend money that way? Well, people make it happen. We get people in and we train them... We're not going to hire you unless you've been subbing for us. I want to know that you can handle that class. I want to know that you can teach SFA. I want to know that you can get data and research and utilize it accordingly. So I'm not hiring you off the street. Have you been with us? Have you been a sub? ... Have you been with us for 55 days subbing so we can evaluate you? Now we'll talk.

Middleville is very savvy on this human resources issue. In many school districts, once a teacher is in the system and obtains tenure the district is limited in its ability to remove that teacher if she or he turns out to be a poor fit within the system. However, for Middleville, substitute teachers provide an interesting and novel avenue for approaching this issue. Middleville views its substitute teachers as trial teachers for Middleville. The district hires substitutes for extended periods (100-days), invests heavily in them by training them in SFA, and then not only is the district able to see if the substitute teacher is a good fit with Middleville, but substitutes are able to see if the district is a good fit for them. In this way, Middleville treats its substitutes not as ad hoc replaceable staff but as opportunity hires on a trial basis. Over time, this selective hiring practice has enriched Middleville's 
teaching faculty with teachers pre-trained in SFA, who are known to already agree with the program and how the district has implemented it, and are already acquainted with and part of the district culture. This gives Middleville an ever increasing advantage in time over its peers throughout its state. In addition, by having long-term substitutes trained in the core technology of SFA, the district is able to continue to educate the students in the absence of their regular teacher, and keep those students on pace with the instructional materials provided by SFA. This point was summarized well by an elementary teacher who said:

We train subs when they come in... like [a recent hire] when they interviewed her, when she was doing her subbing [for Middleville] she actually went to the in-services [for SFA] ... a lot of subs did that, so they weren't going in [to classrooms] cold-turkey... so you don't feel so bad when you're not there [in the classroom] because [the subs] are doing what they're supposed to do.

Through the combination of the disciplined system of SFA and this human resource strategy, the children who are taught by a substitute lose less time in comparison with their peers throughout the district, and are instructed by qualified and trained teachers. Over time this "extra" instruction adds up, relative to districts where substitutes may perform below par and the regular teacher must "catch up" the class before moving ahead. Additionally, Middleville administrators can feel confident that if they schedule substitutes to fill in when full-time teachers meet on collaborative and professional development activities, those teacher's classrooms will remain on-pace and will receive adequate instruction, so that no time is lost, and students will be on-track. However, this type of professional development practice takes money, so that fiscal practices also distinguish high performing organizations.

\section{Funneling Budgetary Resources to District Priorities}

District 2 and Good to Great both provide clear examples of management's use of limited budgetary resources to fund systems that align with the core commitments of the organization; and to re-allocate funds internally to better support the "hedgehog" concept. For District 2 this was termed "multi-pocket budgeting" where funds from multiple external streams, such as Title I and special education, are redirected within the organization to support district priorities that may loosely align with federal or state mandates on the uses of those monies, but that align well with the core purposes of the organization (Elmore \& Burney, 1999). In District 2, this meant that funding from Title I, state magnet school categorical funding, local tax revenues and special education, were all directed to support teacher professional development, instructional consultants, and teacher and substitute salaries during professional development. In Good to Great, budgeting and funding are treated in similar fashion. Budgeting is about deciding "which arenas should be fully funded and which should not be funded at all . . . [it] is not about figuring out how much each activity gets, but about determining which activities best support the Hedgehog Concept" (Collins, 2001, p.140). Together, these two studies point to a very specific budgeting strategy, that all incoming funds must be acquired and/or directed to the priority of the organization, and that if extra funding is needed in the service of that priority then it should be redirected from any other funding streams available. This does not mean that funding streams such as Title I should be redirected to programs that do not serve the mandated population, such as disadvantaged children. Rather, the hedgehog concept dictates a tight focus, and for a school that necessarily includes teaching all children well. For District 2, increasing professional development around the core concept of improving instruction within the Balanced Literacy program was a creative use of Title I funds. In similar fashion, Middleville also adopted a multi-pocket budgeting strategy to fund its core concept.

Middleville used multi-pocket budgeting in many ways to fund the district's initiatives. When asked about funding the district's programs, the district treasurer said, the "program is what generates the monies, not the monies generate the program . . . It's not the monies that dictate what goes on with the program. We devise a program and then we develop the resources around [it]." That development of resources was discussed by the assistant superintendent in specific reference to how the district was able to fund the heavy professional development requirements of SFA:

[With SFA] you have to commit that you'll have a facilitator at each building. Well, we used our Title I teachers at the building level [as facilitators] ... [With SFA] you have to do a lot of professional development, so after our staff voted to accept it, we put all our resources together. We applied for a [state reading grant] ... We were able to buy the materials that we needed. We were able to get our staff trained with the professional development [for SFA] using our Title I funds and [the grant monies].

When Middleville decided to adopt SFA, funding had to be found to fully implement it. As the treasurer stated, program first, then funding. For SFA, once it was decided that the program was a good fit for the district, grants were written, staff were reassigned and followed the money, and funding was redirected from multiple sources to support the project. This stands in sharp contrast to what have become known as "Christmas tree" schools (Bryk et al., 1999) where multiple and often conflicting instructional and student enrichment programs are added haphazardly as individual teachers and administrators champion favored programs. The difference, as detailed in District 2, Good to Great, and in Middleville, is that the programs selected for funding through multi-pocket budgeting adhere to the hedgehog concept of the organization, and thus are seen to be smaller pieces that fit within the whole of the disciplined system that aligns the work of the entire organization. Middleville is a prime example of multi-pocket budgeting in action, where disciplined systems are chosen that align with the core concept of the organization, and then, only after the programs are chosen, is funding channeled to that program.

\section{Long-term Faith and Continuous Improvement}

A final finding from the District 2 and Good to Great studies concerns the ability of successful organizations to sustain faith in their long-term success as an absolute, while also identifying and acting on the hard facts facing the organization in the present. For each successful company in the Good to Great study one of the main differences when compared to an underperforming peer was that no matter how bad the news facing the company, the leaders always retained faith that the company would succeed in the end, while at the same time resolutely confronting those hard facts facing them (Collins, 2001). This finding also appears in the 
District 2 study. At the time of the study, District 2 was one of the most diverse school districts in New York City, with students from every corner of the world speaking a multitude of languages, with a majority of the schools having between 70 to 100 percent children from poor families. Test scores were very low, as one might expect. The outlook for such a district would seem to be bleak. Yet from the start of the District 2 reforms in 1987 to when the top administrators left the system in 1999, the leadership of District 2 stated their belief in the long-term success of the district while acknowledging that success would be a long, multistage endeavor that would require the teaching staff and administrators to work hard together to create collaborative solutions in service to their students. With the core commitment that the purpose of the organization was to improve instruction for every student, the leadership of District 2 was able to retain the long-term faith in the eventual success of the district, while focusing the organization on the problems at hand. Combined, the cases of District 2 and Good to Great point to the leadership always maintaining high long-term expectations for the organization while concurrently focusing on the slow but steady work of continuous improvement.

This concept of long-term faith in the organization's success coupled with continuous improvement is exemplified by Middleville. Across the school district, interviews with teachers, administrators and parents indicated that the vast majority of participants in the organization held very similar long-term aspirations for all, rather than a few schools in the district. This district-wide focus on the long-term success of the entire organization - system-wide thinking - appears to be one of the factors in Middleville's success. At the same time, coupled with this system-wide, long-term belief in success is the near-term acknowledgement that much work remains. So for all of Middleville's success at the elementary level, state test scores for the high school indicate that the district is behind the state averages in mathematics, reading, and writing (see Figure 1). Thus, the district has the aspiration of being one of the best districts in the state, but they recognize that the high school is not performing yet at the level of their aspirations so they are developing a long-range strategy, of which some elements are apparent at this writing.

First, Middleville's district administrators are working on a plan to address the issue of lagging performance at the high school level. Most important to the plan is the fact that at the time of this study, the students who were attending the middle school were the same students for whom the district had begun the SFA program and had seen such success. As the first students from the SFA system for all of their elementary careers began to enter the middle school, the administration saw that it had an opportunity. While the district does not have an SFA system for either the middle school or the high school it knows that the vast majority of its students entering its middle school are on grade level, and it knows exactly which children are not, and which curricular components those children are having difficulties with. So the district is changing the instructional system slowly, over time, following the "SFA kids" into the higher levels and modifying those levels as the students reach them.

The first stage of this project is beginning at the middle school level. For reading, the district invested in a greater variety of more complex books and novels as the students have moved up from the elementary school and the students themselves have begun demanding more complex reading materials. For mathematics, the district intends to modify the daily class schedule to incorporate two math periods at the middle school, one as a traditional instructional period and a second using computer assisted instruction as a modality to give daily feedback to students, teachers, and administrators on each student's progress on grade-level in mathematics - which fits directly into the district's hedgehog concept. To find space in the schedule, the district has reassigned art and physical education teachers to "travel" to each of the elementary schools during each week of the school year, to provide art and physical education programs that were not being provided previously at the elementary level, freeing up those hours in the middle school schedule to provide the double math period. This again is another example of systems thinking coupled with disciplined action around the hedgehog concept. When the entire district is viewed as a system of schools by the administration, rather than a collection of independent buildings, the administration can focus on creating an overall disciplined approach in which each program adheres to the hedgehog concept. Funding and human resources are then directed in service to the entire system, creating opportunities for piloting innovative solutions to the hard problems facing the school district, such as increasing mathematics competency at the higher grade levels. While Middleville presently may be quite good, they have entered on what Collins might consider the path from good to great.

\section{DISCUSSION}

This study offers these comparisons as leads for how successful organizations become successful, highlighting specific concepts (see Table 1). First, the successful organizations studied all created consistent and coherent systems in which boundaries and expectations were set, but individuals then were free to innovate within those systems. Second, while a long-term vision is important, it is the hedgehog concept of the successful organization that drives and focuses that organization forward; identifying and communicating the main objective as paramount. Third, having the right people in the organization is critical, and for education, finding and hiring those right people is a key priority of district administrators. Fourth, the organization's hedgehog concept serves to focus acquisition and allocation of resources to the exclusion of other funding opportunities that vie for attention. Fifth, the successful organizations all had faith in the long-term success of that organization while confronting and responding creatively to the hard facts facing the organization. Taken together these organizational features seem to be associated centrally with their success.

But there are counter-arguments to consider. Programs such as SFA have recently come under criticism. Opponents indict structured school-wide programs such as SFA as regimented and scripted lock-step systems utilized mainly to "educate" poor and minority students (Kozol, 2005). Others contend that reforms of this kind narrow the curriculum to just a few subjects (e.g., math, reading) and teach to the tests. Overall then this critique finds fault with both the accountability orientation in state and federal policy and in particular programs like SFA that offer limited and standard solutions to the complex problems of schools, families, and communities in urban and rural poor America. While these arguments may have merit, especially in the districts discussed by Kozol, evidence from the successful implementation of SFA in Middleville suggests that 1 ) teachers have come to own and adopt the program; 2) they report considerable and unexpected success; and 3) the consistency of program routines has created a viable 
basis for a teacher learning community and for appropriate instructional oversight.

Recent studies also have highlighted the systemic changes undertaken in the San Diego public school system, in which many of the reforms of District 2 were attempted and expanded upon (Cuban \& Usdan, 2003; Hannaway \& Stanislawski, 2005). These reforms included a heavy emphasis and funding for professional development, firing and reorganizing a large section of the central office around instructional leadership and development, and creating a coherent system-wide curriculum focused on high quality instructional materials and pedagogy (Hightower \& McLaughlin, 2005). While many of the reforms in San Diego align with the conclusions of this study, the jury is out on whether the reforms there have worked. From the perspective of this study, it may be that after only six years of reform, it is still too early to tell if San Diego will outpace similar urban districts such as Long Beach, Los Angeles, or Oakland in performance assessments. As well, District 2 only served children up to the $8^{\text {th }}$ grade, and as shown with Middleville, reform and success at the elementary level may come quickly, but solving issues of low performance at higher educational levels is more difficult. In addition, as with Middleville, whole-district reforms may require enough time for one whole cohort to matriculate through the entire newly reformed system, before gains are realized. For Middleville this has meant that major reforms for the upper grades must wait for the "SFA kids," children who have received instruction only under the district's reformed instructional approach, to reach those upper grades. Such district-wide reforms would take at least 12 years to begin to realize gains as children work their way through the entire system, but more likely 14 to 15 years as the first years of a reform are frequently spent in flux. Timespans for true reform are likely to be much longer than are typically reckoned.

Additionally, a critique of this study is that it approaches the overall theory and data analysis from a technical-rational perspective (Datnow et al., 2002), a top-down management oriented lens, examining the data to explore the evidence for the combined Good to Great and District 2 theory. The author acknowledges that analysis of the data from a technical-rational perspective may be a somewhat over-simplified approach. This does not deny that organizational reforms are co-constructed by multiple participants up and down the system, but rather this study emphasizes that central administration can be part of significant actions in developing system-wide coherence.

As with all case study work, context matters. The effect of context and location must be acknowledged since implementation of reforms can take on very different meanings across different schools and school districts (Elmore \& Sykes, 1992). This is especially true when studying whole school reforms (Datnow et al., 2002) and their effectiveness, and should be considered as an alternative explanation for district and school success. Similarly the Middleville context matters because this is a case in which trust is high and stable between the community and the district as well as labor and the district. Additionally, Middleville teacher turnover and student mobility rates are fairly low. Because both teachers and students were present year-to-year, it must be acknowledged that Middleville may have found success with SFA because teachers were able to work for multiple years on the same program together and students were matriculating through a single system year-to-year. However this alternative explanation is tempered when the low teacher turnover is considered as additional evidence for the district's success, both in its innovative hiring practices detailed above and its success with its students, which both the District 2 and Good to Great studies would suggest would help to keep teachers motivated to stay in the Middleville system. Also, much of the success of Middleville could be attributed to simply implementing SFA well, but this point as well supports the initial findings presented here of the use of an organization-wide disciplined system in combination with the other main points of the combined theory.

In conclusion, the five key aspects of high performing organizations drawn from two prominent studies have apt parallels in the case of Middleville. These aspects may be generalizable to many different types of organizations and align well with the concept of instructional regimes (Cohen et al., 2003). Acknowledging that this study presents only initial evidence in support of the combined theory from a single school district, it would be interesting to test the convergent account presented in this study in multiple situations across different types of organizations, from non-profits to large urban, suburban and rural school districts. Future work will concentrate on identifying a greater variety of cases and testing the generalizability of common features such as these.

\section{ACKNOWLEDGEMENTS}

This work has been supported through a generous grant from the William and Flora Hewlett Foundation, Grant: 2004-4151.

The author would like to thank Gary Sykes and for his support of this study and his thoughtful review of this manuscript, as well as Susan Printy for her work on the study and her thoughtful review of this manuscript.

\section{RECOMMENDED CITATION FORMAT}

Bowers, A.J. (2008) Promoting Excellence: Good to Great, NYC's District 2, and the Case of a High Performing School District, Leadership and Policy in Schools, 7(2), 154-177. doi:10.1080/15700760701681108

\section{REFERENCES}

Berlin, I. (1953). The hedgehoge and the fox: An essay on Tolstoy's view of history. New York: Simon \& Schuster.

Borman, G. D., Slavin, R. E., Cheung, A. C. K., Chamberlain, A. M., Madden, N. A., \& Chambers, B. (2005). The national randomized field trial of Success For All: Second-year outcomes. American Educational Research Journal, 42(4), 673-696.

Bryk, A. S., Bebring, P. B., Kerbow, D., Rollow, S., \& Easton, J. Q. (1999). Charting Chicago school reform: Democratic localism as a lever for change: Westview Press, Boulder Colorado.

Coe, R., \& Taylor-Fitz-Gibbon, C. (1998). School effectiveness research: Criticisms and recommendations. Oxford Review of Education, 24(4), 421-438.

Cohen, D. K., Raudenbush, S. W., \& Ball, D. L. (2003). Resources, instruction and research. Educational Evaluation and Policy Analysis, 25(2), 119-142.

Collins, J. (2001). Good to great. New York: HarperCollins Publishers.

Collins, J. (2005). Good to great and the social sectors: A monograph to accompany good to great: Jim Collins, Boulder Colorado.

Cuban, L., \& Usdan, M. (2003). Fast and top-down: Systemic reform and student achievement in San Diego city 
schools. In L. Cuban \& M. Usdan (Eds.), Powerful reforms with shallow roots (pp. 77-95). New York: Teachers College Press.

Datnow, A., \& Castellano, M. (2000). Teachers' responses to success for all: How beliefs, experiences, and adaptations shape implementation. American Educational Research Journal, 37(3), 775-799.

Datnow, A., Hubbard, L., \& Mehan, H. (2002). Extending educational reform. New York: RoutledgeFalmer.

Elmore, R. F., \& Burney, D. (1997). School variation and systemic instructional improvement in Community School District \#2, New York City (No. ED 429-264). Pittsburgh: Pittsburgh University.

Elmore, R. F., \& Burney, D. (1999). Investing in teacher learning: Staff development and instructional improvement. In L. Darling-Hammond \& G. Sykes (Eds.), Teaching as the learning profession: Handbook of policy and practice (pp. 263-291). San Francisco: Jossey-Bass.

Elmore, R. F., \& Sykes, G. (1992). Curriculum policy. In P. Jackson (Ed.), Handbook of research on curriculum. New York: Macmillan.

Fink, E., \& Resnick, L. B. (2001). Developing principals as instructional leaders. Phi Delta Kappan, 82(8), 598606.

Goldstein, H., \& Woodhouse, G. (2000). School effectiveness research and educational policy. Oxford Review of Education, 26(3/4), 353-363.

Hallinger, P., \& Heck, R. H. (2002). What do you call people with visions? The role of vision, mission and goals in school leadership and improvement. In K. Leithwood \& P. Hallinger (Eds.), Second international handbook of educational leadership and administration (pp. 9-40). Norwell Mass.: Kluwer Academic Publishers,

Hannaway, J., \& Stanislawski, M. (2005). Flip-flops in school reform: An evolutionary theory of decentralization. In F. M. Hess (Ed.), Urban school reform: Lessons from San Diego (pp. 53-70). Cambridge, Mass.: Harvard Education Press.

Hightower, A. M. (2002). San Diego's big boom: Systemic instructional change in the central office and schools. In A. M. Hightower, M. S. Knapp, J. A. Marsh \& M. W. McLaughlin (Eds.), School districts and instructional renewal (pp. 76-93). New York: Teachers College Press.

Hightower, A. M., Knapp, M. S., Marsh, J. A., \& McLaughlin, M. W. (2002). The district role in instructional renewal: Setting the stage for dialogue. In A. M. Hightower, M. S. Knapp, J. A. Marsh \& M. W. McLaughlin (Eds.), School districts and instructional renewal (pp. 1-6). New York: Teachers College Press.

Hightower, A. M., \& McLaughlin, M. W. (2005). Building and sustaining an infrastructure for learning. In F. M. Hess (Ed.), Urban school reform: Lessons from San Diego (pp. 71-92). Cambridge, Mass.: Harvard Education Press.

Kozol, J. (2005). The shame of the nation: The restoration of apartheid schooling in America. New York: Crown Publishers.

Marsh, J. (2002). How districts relate to states, schools and communities: A review of emerging literature. In A. M. Hightower, M. S. Knapp, J. A. Marsh \& M. W. McLaughlin (Eds.), School districts and instructional renewal (pp. 25-40). New York: Teachers College Press.
McLaughlin, M. W., \& Talbert, J. E. (2002). Reforming districts. In A. M. Hightower, M. S. Knapp, J. A. Marsh \& M. W. McLaughlin (Eds.), School districts and instructional renewal (pp. 193-202). New York: Teachers College Press.

Murphy, J., \& Hallinger, P. (2001). Characteristics of instructionally effective school districts. Journal of Educational Research, 81(3), 175-181.

Peters, T., \& Waterman, R. H. (1982). In search of excellence: Lessons from America's best run companies. New York: Harper \& Row.

Raudenbush, S. W. (2005). Learning from attempts to improve schooling: The contribution of methodological diversity. Educational Researcher, 34(5), 25-31.

Skrla, L., \& Scheurich, J. J. (2004). Displacing deficit thinking in school district leadership. In L. Skrla \& J. J. Scheurich (Eds.), Educational equity and accountability (pp. 109132). New York: RoutledgeFamler.

Slavin, R. E., \& Madden, N. A. (2001a). Success for all: An overview. In R. E. Slavin \& N. A. Madden (Eds.), Success for all: Research and reform in elementary education (pp. 3-16). Mahwah: Lawrence Erlbaum Associates.

Slavin, R. E., \& Madden, N. A. (2001b). Summary of research on success for all and roots and wings. In R. E. Slavin \& N. A. Madden (Eds.), Success for all: Research and reform in elementary education (pp. 17-48). Mahwah: Lawrence Erlbaum Associates.

Smith, M. S., \& O'Day, J. A. (1991). Systemic school reform. In S. H. Fuhrman \& B. Malen (Eds.), The politics of curriculum and testing: The 1990 yearbook of the poltics of education association (pp. 233-267). New York: The Falmer Press.

Snyder, J. (2002). New Haven unified school district: A teaching quality system for excellence and equity. In A. M. Hightower, M. S. Knapp, J. A. Marsh \& M. W. McLaughlin (Eds.), School districts and instructional renewal (pp. 94-110). New York: Teachers College Press.

Standard, \& Poor's. (2005). www.schoolmatters.com: Standard \& Poor's.

Stein, M. K., \& D'Amico, L. (2002a). The district as a professional learning laboratory. In A. M. Hightower, M. S. Knapp, J. A. Marsh \& M. W. McLaughlin (Eds.), School districts and instructional renewal (pp. 76-93). New York: Teachers College Press.

Stein, M. K., \& D'Amico, L. (2002b). Inquiry at the crossroads of policy and learning: A study of a district-wide literacy initiative. Teachers College Record, 104(7), 1313-1344.

Supovitz, J. A. (2006). The case for district-based reform: Leading, building, and sustaining school improvement. Cambridge, Massachusetts: Harvard Education Press.

Teddlie, C., Reynolds, D., \& Sammons, P. (2000). The methodology and scientific properties of school effectiveness research. In C. Teddlie \& D. Reynolds (Eds.), The international handbook of school effectiveness research (pp. 55-134). New York, NY: Falmer Press.

Thrupp, M. (2001). Recent school effectiveness counter-critiques: Problems and possibilities. British Educational Research Journal, 27(4), 443-457.

Yin, R. K. (2003). Case study research: Design and methods (3rd ed.). Thousand Oaks: Sage. 